\title{
Perancangan Alat Pengering Kain Berdasarkan Kesehatan dan Keselamatan Kerja Menggunakan Metode Swift di Industri Tekstil Cap Jempol
}

\author{
Muhammad Hasan ${ }^{* 1}$, Rahmaniyah Dwi Astuti ${ }^{2}$, dan Irwan Iftadi ${ }^{3}$ \\ Teknik Industri, Fakultas Teknik, Universitas Sebelas Maret, \\ J1.Ir Sutami No.36 A,Surakarta,57126,Indonesia \\ Email: zmuhammad1805@gmail.com ${ }^{1}$
}

\begin{abstract}
Abstrak
Industri tekstil merupakan salah satu usaha yang cukup banyak diminati oleh masyarakat dan menyerap banyak tenaga kerja di Indonesia. Hasil produk dari industri tekstil sudah tersebar luas di seluruh daerah di Indonesia.Tingginya permintaan tekstil memicu peningkatan perkembangan industri tekstil baik dalam skala kecil hingga skala besar, salah satunya di Industri Cap Jempol.Pada penelitian ini menggunakan analisis kesehatan dan keselamatan kerja. Untuk Penilain Resiko Kecelakaan kerja dengan pada stasiun pengeringan menggunakan metode SWIFT . Dan untuk usulan perbaikan fasilitas dengan menggunakan metode NIDA.
\end{abstract}

Kata kunci: industri tekstil, SWIFT, NIDA, kesehatan keselamatan kerja.

Abstract

Textile Industry is the one of the famous Industry which is absorb a lot of people workers in Indonesia. The product of the Textile Industry is distributed a lot of city in Indonesia, High Demand of Textile is affected increased of Textile Industry scale from small scale till big scale Textile Industry. One of them is Cap Jempol Textile Industry. This research is use bout Occupational Health and Safety Analysis. For the Risk Management is use SWIFT methode for the drying station.For the Reccomendation Improvement is use NIDA methode.

Keywords: textile industry, SWIFT,NIDA, occupation health and safety

\section{Pendahuluan}

Industri tekstil merupakan salah satu usaha yang cukup banyak diminati oleh masyarakat dan menyerap banyak tenaga kerja di Indonesia. Hasil produk dari industri tekstil sudah tersebar luas di seluruh daerah di Indonesia. Harga dari produk tekstil juga sangat beragam, dari skala rendah hingga skala tinggi. Permintaan atas kebutuhan tekstil juga meningkat setiap tekstilnnya. Tingginya permintaan tekstil memicu peningkatan perkembangan industri tekstil baik dalam skala kecil hingga skala besar.

Keselamatan dan Kesehatan kerja sangatlah penting bagi perkerja. Menurut Ima Ismara. dkk (2014), Keselamatan dan Kesehatan Kerja (K3) adalah melindungi keselamatan dan kesehatan para pekerja dalam menjalankan pekerjaannya, melalui upaya-upaya pengendalian semua bentuk potensi bahaya yang ada di lingkungan tempat kerjanya.

Untuk mendapatkan data mengenai risiko kecelakaan kerja dilakukan proses wawancara. Bentuk wawancara yaitu wawancara tertutup dengan mewawancarai Bapak Hasan selaku pemilik dan Aji dan
Sapto selaku operator. Berdasarkan data hasil wawancara dengan pemilik dan operator, meja cetak yang terbakar dan api yang mengenai operator sehingga menimbulkan cidera menjadi dua hal yang sering terjadi.

Berdasarkan permasalahan yang telah diuraikan, maka diperlukan adanya penelitian lebih lanjut dalam proses produksi tekstil di Industri Tekstil Cap Jempol, khususnya pada proses pengeringan. Dari permasalahan yang timbul, penyebab dari permasalahan yaitu alat pengering kain yang terbilang membahayakan . Hal itu terbukti dengan adanya kerusakan pada meja cetak dan luka yang pernah dialami oleh operator akibat api yang tidak stabil dari alat pengering kain. Untuk mengurangi bahaya tersebut dapat dilakukan dengan adanya perancangan suatu alat bantu kerja yang lebih aman dengan Metode SWIFT . Metode SWIFT dinilai tepat karena dapat menilai permasalahan dengan akurat dan sesuai dengan kondisi yang saat ini terjadi

\footnotetext{
* Penulis korespondensi
} 


\section{Metode Penelitian}

Metode SWIFT dan NIDA digunakan dalam penelitian ini. Menurut Hakim (2015), SWIFT merupakan suatu teknik dalam mengidentifikasi bahaya dengan kreativitas dan berdasarkan kemampuan analisis dari anggota tim dalam mengembangkan, mempersiapkan daftar periksa yang dapat mengungkapkan kemungkinan bahaya yang terjadi dalam unit proses. Menurut Andriana dkk. (2017) proses perancangan yang merupakan tahapan umum teknik perancangan dikenal dengan sebutan NIDA, yang merupakan kepanjangan dari need (perlu), idea (gagasan), decision (keputusan) dan action (tindakan). Tahapan pertama adalah menentukan kondisi kerja yang beresiko membahayakan operator atau tidak dengan menggunakan metode SWIFT, selanjutynya apabila beresiko maka akan dilakukan perbaikan dengan Metode NIDA.Pengambilan data dilakukan dari Oktober 2020 selama 10 hari .

Langkah-langkah dalam melakukan Pengumpulan dan Pengolahan data sebagai berikut :

\section{Melakukan Studi Literatur dari Penelitian Sebelumnya}

Studi Literatur sebelumnya digunakan untuk menyusun segala informasi yang bisa didapat terkait dengan penelitian ini. Literatur diambil dari Alan J Card (2012) dan Hans Torvatn (2002)

\section{Metode SWIFT}

Terdapat risiko kecelakaan kerja pada setiap aktivitas proses produksi kain khususnya pada proses pengeringan kain di Industri Tekstil Cap Jempol. Menurut Alan J Card (2012) metode yang dapat digunakan untuk mengurangi risiko kecelakaan kerja yang tinggi pada penggunaan atau pengoperasian sebuah peralatan utama dan kritikal adalah metode SWIFT.

\section{Metode NIDA}

Menurut Hans Torvatn (2002) pada tahap ini dilakukan perancangan usulan fasilitas kerja menggunakan konsep perancangan NIDA (Need, Idea, Decision, dan Action) untuk memberikan usulan perbaikan.

\section{Hasil dan Pembahasan}

Pada bagian ini akan dijelaskan tentang proses pengeringan kain di Industri Batik Cap Jempol meliputi beberapa tahap :

1. Mengambil Alat Pengering kain

2. Memasang Gas pada alat pengering kain

3. Melakukan Set Up alat pengering kopi

4. Proses Pengering kain

5. Persiapan proses selanjutnya

Dari proses pengeringan kain terdapat beberapa risiko kecelakaan kerja. Tabel 1 menjelaskan rekapitulasi risiko-risiko apa saja yang terjadi saat proses pengeringan kain dan frekuensi dalam setiap proses pengeringan kain.
Tabel 1. Rekapitulasi risiko kecelakaan kerja

\begin{tabular}{|c|c|c|}
\hline Proses ke & Risiko & Frekuensi \\
\hline \multirow{3}{*}{1} & Api mengenai tabung gas & 4 \\
\hline & Api mengenai operator & 2 \\
\hline & Operator terpapar panas terlalu lama & 1 \\
\hline \multirow{3}{*}{2} & Api mengenai tabung gas & 3 \\
\hline & Api mengenai operator & 1 \\
\hline & Kain terbakar akibat ban macet & 1 \\
\hline \multirow{3}{*}{3} & Api mengenai tabung gas & 6 \\
\hline & Gas terlalu panas akibat terpapar api & 1 \\
\hline & Operator terpapar panas terlalu lama & 1 \\
\hline \multirow{4}{*}{4} & Api mengenai tabung gas & 3 \\
\hline & Api mengenai operator & 2 \\
\hline & Gas terlalu panas akibat terpapar api & 1 \\
\hline & Operator terpapar panas terlalu lama & 1 \\
\hline \multirow{2}{*}{5} & Api mengenai tabung gas & 4 \\
\hline & Operator terpapar panas terlalu lama & 1 \\
\hline \multirow{2}{*}{6} & Api mengenai tabung gas & 4 \\
\hline & Gas terlalu panas akibat terpapar api & 1 \\
\hline \multirow{3}{*}{7} & Api mengenai tabung gas & 5 \\
\hline & Api mengenai operator & 2 \\
\hline & Operator terpapar panas terlalu lama & 2 \\
\hline \multirow{4}{*}{8} & Api mengenai tabung gas & 4 \\
\hline & Api mengenai operator & 2 \\
\hline & $\begin{array}{l}\text { Kain terbakar karena alat pengering } \\
\text { membentur meja cetak }\end{array}$ & 1 \\
\hline & Operator terpapar panas terlalu lama & 2 \\
\hline \multirow{2}{*}{9} & Api mengenai tabung gas & 5 \\
\hline & Gas terlalu panas akibat terpapar api & 1 \\
\hline \multirow{4}{*}{10} & Api mengenai tabung gas & 4 \\
\hline & Api mengenai operator & 2 \\
\hline & Gas terlalu panas akibat terpapar api & 1 \\
\hline & Operator terpapar panas terlalu lama & 2 \\
\hline
\end{tabular}

Proses pengukuran dimensi alat pemanas kain yang digunakan dilakukan dengan cara mengukur mengukur setiap dimensi alat menggunakan meteran dan dicatat setiap dimensinya. Pengukuran dilakukan sebelum proses pemanasan kain berlangsung. Data dimensi digunakan untuk data yang digunakan dalam proses merancang alat pengering kain baru. Tabel 2 menjelaskan ukuran part yang digunakan untuk proses perancangan desain.

Tabel 2. Daftar nama dan ukuran part alat pengering kain

\begin{tabular}{ll}
\hline Nama Part & Ukuran \\
\hline Panjang badan meja & $140 \mathrm{~cm}$ \\
Lebar badan meja & $80 \mathrm{~cm}$ \\
Tinggi badan meja & $28 \mathrm{~cm}$ \\
Jarak antara kaki meja dengan badan meja & $20 \mathrm{~cm}$ \\
Tinggi kaki meja & $75 \mathrm{~cm}$ \\
Lebar kaki meja & $5 \mathrm{~cm}$ \\
Diameter ban & $5 \mathrm{inch}$ \\
Sisi lubang selang gas & $5 \mathrm{~cm}$ \\
Panjang tempat meletakan gas & $35 \mathrm{~cm}$ \\
Lebar tempat meletakan gas & $35 \mathrm{~cm}$ \\
Tinggi tempat meletakan gas & $30 \mathrm{~cm}$ \\
\hline
\end{tabular}

Pengolahan Data dilakukan dengan mengolah data risiko-risiko yang terjadi,waktu pengeringan, 
analisis dan analisis faktor penyebab terjadinya risiko kecelakaan kerja menggunakan metode SWIFT (Structured What If Technique).

Perhitungan risiko kecelakaan kerja menggunakan metode SWIFT (Structured What If Technique). Terdapat 10 data hasil pengambilan yang diolah dan digunakan untuk menilai risiko-risiko apa saja yang membahayakan operator dan harus diperbaiki. Tabel 3 menjelaskan risiko apa saja yang terjadi saat proses pengeringan kain.

Tabel 3. Daftar risiko kecelakaan kerja

\begin{tabular}{ll}
\hline No & Risiko \\
\hline 1 & Api mengenai tabung gas \\
2 & Api mengenai operator \\
3 & Gas terlalu panas akibat terpapar api \\
4 & Operator terpapar panas terlalu lama \\
5 & Kain terbakar akibat ban macet \\
6 & Kain terbakar karena alat pengering membentur meja cetak \\
\hline
\end{tabular}

Analisis Structured What If Techinque (SWIFT) merupakan salah satu metode yang digunakan untuk menilai risiko kecelakaan apa saja yang mungkin dapat menimbulkan terjadinya kecelakaan kerja. Dari hasil rekap dan analisis terdapat kebutuhan akan perbaikan alat yang dilakukan seperti pada tabel 4 .

Tabel 4. Hasil análisis SWIFT

\begin{tabular}{|c|c|c|c|}
\hline No & Risiko & $\begin{array}{l}\text { Nilai Rata- } \\
\text { Rata RRN }\end{array}$ & Kategori \\
\hline 1 & $\begin{array}{l}\text { Api mengenai } \\
\text { tabung gas }\end{array}$ & 17.2 & $\begin{array}{l}\text { Prioritas utama } \\
\text { (dibutuhkan tindakan } \\
\text { secepatnya) }\end{array}$ \\
\hline 2 & $\begin{array}{l}\text { Api mengenai } \\
\text { operator }\end{array}$ & 3.6 & $\begin{array}{l}\text { Prioritas rendah (risiko } \\
\text { yang tidak terlalu } \\
\text { berbahaya) }\end{array}$ \\
\hline 3 & $\begin{array}{l}\text { Gas terlalu panas } \\
\text { akibat terpapar api }\end{array}$ & 2.4 & $\begin{array}{l}\text { Prioritas rendah (risiko } \\
\text { yang tidak terlalu } \\
\text { berbahaya) }\end{array}$ \\
\hline 4 & $\begin{array}{l}\text { Operator terpapar } \\
\text { panas terlalu lama }\end{array}$ & 6.3 & $\begin{array}{l}\text { Prioritas menengah } \\
\text { (risiko yang } \\
\text { signifikan) }\end{array}$ \\
\hline 5 & $\begin{array}{l}\text { Kain terbakar } \\
\text { akibat ban macet }\end{array}$ & 0.02 & Prioritas paling rendah \\
\hline 6 & $\begin{array}{l}\text { Kain terbakar } \\
\text { karena alat } \\
\text { pengering } \\
\text { membentur meja } \\
\text { cetak }\end{array}$ & 0.01 & Prioritas paling rendah \\
\hline
\end{tabular}

Perancangan menggunakan aplikasi Autodesk Inventor. Keputusan rancangan desain dapat dilihat dalam gambar.

\section{a) Alternatif Desain I}

Pada alternatif desain 1, pegangan tangan kanan dan tangan kiri dibuat terpisah. Pegangan tangan kiri dibuat tidak bisa bergerak atau fixed yang fokus untuk memberi dorongan kedepan, sedangkan pegangan tangan kanan dipasang dari ujung depan sisi kanan alat dan dirancang bisa bergerak untuk membuat handling alat yang lebih mudah. Pada alternatif desain 1, kaki alat juga dibuat adjustable dan dapat diatur tinggi pendeknya yang diharapkan dapat menghemat gas dan meningkatkan efektifitas alat pengering kain.

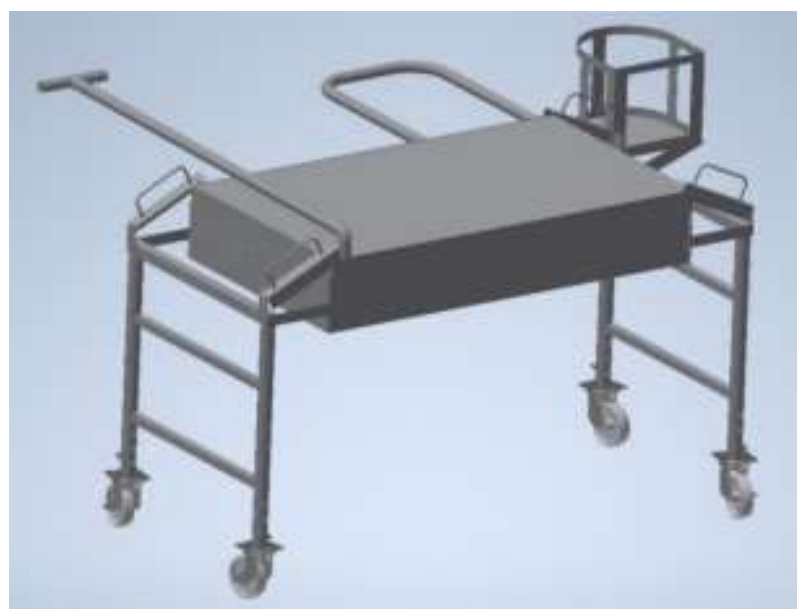

Gambar 1. Alternatif desain 1

b) Alternatif Desain II

Pada alternatif desain 2, pegangan tangan kanan dan tangan kiri dibuat tergabung menjadi satu rangkaian. Desain pegangan tangan dirancang menyatu dari ujung belakang kiri sampai ujung belakang kanan. Pada alternatif desain 2, kaki alat juga dibuat fixed sehingga pengaturan panas hanya berasal dari banyaknya gas yang digunakan. Namun, pada alternatif desain 2 diharapkan dapat menghemat waktu set up alat pengering kain.

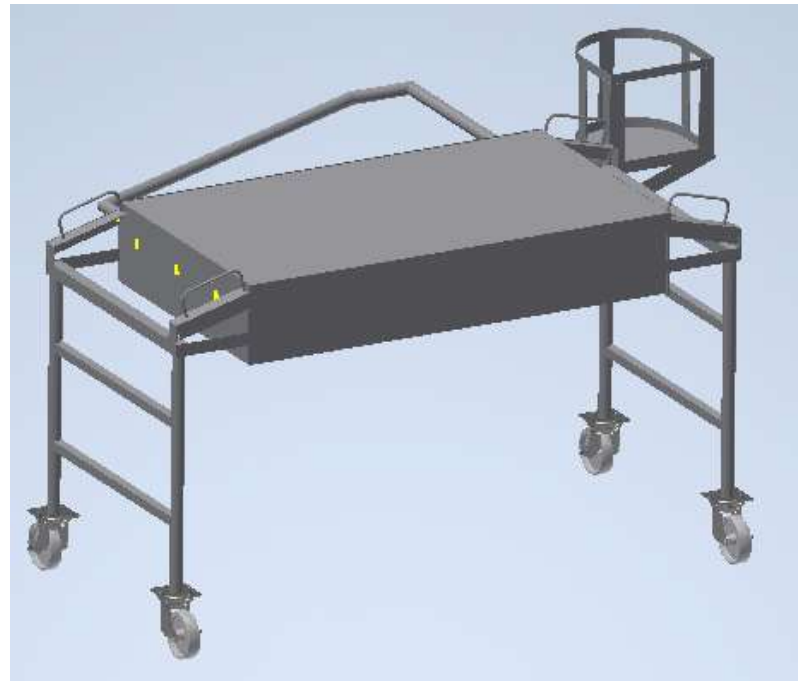

Gambar 2. Alternatif desain 2

\section{Kesimpulan}

Simpulan dari penelitian ini adalah terdapat 2 alternatif desain yang dapat dipakai untuk desain perbaikan. Untuk risiko paparan panas kearah tabung gas dan operator, kedua alternatif sudah dapat mengurangi risiko terjadinya kecelakaan kerja. Alternatif 1 memiliki kelebihan karena memiliki handle yang lebih baik sehingga mengurangi risiko terjadi kecelakaan kerja saat proses pengeringan kain. Sedangkan. Alternatif 1 dipilih karena memiliki kelebihan berdasarkan kesehatan dan keselamatan kerja saat proses pengeringan kain. Berdasarkan hasil wawancara dengan operator dan pemilik Industri Tekstil Cap Jempol setelah menimbang kelemahan dan kelebihan setiap desain, maka diperlukan rancangan fasilitas kerja yang dapat mengkomodasi 
kelebihan serta meminimasi kelemahan dari desain yang tersedia. Oleh karena itu, desain akhir yang dipilih adalah desain pertama yang mana diharapkan bisa lebih aman untuk kesehatan dan keselamatan operator walaupun membutuhkan waktu set up yang lebih lama.

\section{Daftar Pustaka}

Alan J. Card, M. C., James R. Ward, B. C., \& P. John Clarkson, P. B. (2012). Beyond FMEA: The structured what-if technique (SWIFT). Risk Management.

Anthony, M. B. (2020). Analisis Risiko Keselamatan dan Kesehatan Kerja (K3) pada Pengoperasian Overhead Crane Menggunakan Metode SWIFT (Structured What If Technique) di PT. ABC. Jurnal Media Teknik \& Sistem Industri.

Desrianty, A., Prassetiyo, H., \& Ginanjar, G. (2012). Rancangan Sistem Keselamatan Kerja Berdasarkan Metode SWIFT (The Structured What-If Analysis) (Studi Kasus di Stasiun Kerja Belt Grinding Unit PRASKA PT.PINDAD Persero Bandung)

Febriana, N. V., Lestari, E. R., \& Anggarini, S. (2015). Analisis Pengukuran Waktu Kerja Dengan Metode Pengukuran Kerja Secara Tidak Langsung Pada Bagian Pengemaasan Di PT JAPFA COMFEED INDONESIA TBK. Jurnal Industri, 66-73.

Hakim, H. L., Yuniar, \& Irianti, L. (2015). Usulan Perbaikan Sistem Manajemen Keselamatan Dan Kesehatan Kerja (SMK3) Di Pabrik WIRE ROD MILL Berdasarkan Metode SWIFT (Studi Kasus Di PT X).

Hati, S. W. (2015). Analisis Keselamatan Dan Kesehatan Kerja (K3) Pada Pembelajaran Di Laboratorium Program Studi Teknik Mesin Politeknik Negeri Batam.

Huda, L. N., \& Pandiangan, K. C. (2012). Kajian Termal Akibat Paparan Panas dan Perbaikan Lingkungan Kerja. Jurnal Teknik Industri.

Istiqomah, F. H., \& Nawawinetu, E. D. (2013). Faktor Dominan Yang Berpengaruh Terhadap Munculnya Keluhan Subjektif Akibat Tekanan Panas Pada Tenaga Kerja Di PT. IGLAS (PERSERO) Tahun 2013.

Lutfia, C. F., \& Hidayat, S. (2018). Pengukuran Waktu Stasiun Kerja Perakitan Pproduk Meter Air Dengan Metode Jam Henti Pada PT. MULTI INSTRUMENTASI.

Rachmahati, O., Dewi, T. U., \& Rachman, F. (2017). Analisis Pengaruh Lingkungan Kerja dan Karakteristik Individu Terhadap Produktivitas Kerja Serta Perbaikan Hearing Conservation Program. 93-97.

Sadjar, F. S. (2018). Perancangan Fasilitas Kerja Dengan Menggunakan Metode REBA, Quick Exposure Checklist (QEC) dan Keselamatan Kerja di PT. AZWA UTAMA.

Saksvik, P. Ø., Torvatn, H., \& Nytrø, K. (2002). Systematic occupational health and safety work in Norway: a decade of implementation. Safety Science.
Unegbu, N., \& Gudmestad, O. T. (2017). Evaluation of ballast failures during operations of semisubmersible rigs. 